\title{
Argas (Persicargas) persicus (OKen, 1818) (Ixodida: Argasidae) in Sicily WITH CONSIDERATIONS ABOUt ITS ITALIAN AND WEST-MEDITERRANEAN DISTRIBUTION
}

\author{
PANTALEONI R.A.",", BARATTI M.", BARRACO L."*, CONTINI C."*", COSSU C.S.", FILIPPELLI M.T.", \\ LORU L." \& ROMANO M.***.
}

\section{Summary:}

Recently, in the province of Trapani (Western Sicily), some overwintering specimens of the argasid tick Argas (Persicargas) persicus (Oken, 1818) were observed and collected.

Morphological and genetic analysis were utilized in order to reach a definitive identification. The species was found in two semi-natural sites where, having been found repeatedly, its presence does not appear accidental. Moreover the characteristics of the Sicilian findings seem to exclude a human-induced spread. This record, the first regarding Sicily and South Italy, is discussed together with the previous doubtful citations for Italy. These findings revalue not only all the old citations for Italy but also the hypothesis that the Mediterranean distribution of this argasid is of a natural origin.

KEY WORDS: Ixodida, Argasidae, geographic distribution, Italy.
Résumé : ARGAS (PERSICARGAS) PERSICUS (OKEN, 1818) (IXODIDA: ARGASIDAE) EN Sicile AVEC QuelQues CONSIDÉRATIONS SUR SA Distribution en Italie et dans la MéditerRanée occidentale

Récemment, des exemplaires de tique des volailles Argas (Persicargas) persicus (Oken, 1818) en diapause ont été observés et récoltés dans la province de Trapani (Sicile occidentale). L'identification a été confirmée par les analyses morphologiques et génétiques. L'espèce, présente dans deux zones semi-naturelles, a été retrouvée plusieurs fois, ce qui fait paraître sa présence comme non accidentelle. En plus, les caractéristiques des découvertes siciliennes paraissent exclure une diffusion anthropique. Cette signalisation, la première concernant la Sicile et l'Italie du sud, est discutée avec d'autres précédentes citations suspectées mais non confirmées pour l'Italie. Ces découvertes remettent en valeur non seulement les anciennes citations pour l'Italie, mais aussi l'hypothèse que la distribution méditerranéenne de la tique des volailles est effectivement d'origine naturelle.

MOTS CLÉS : |xodida, Argasidae, distribution géographique, Italie.

\section{INTRODUCTION}

\section{1} rgas (Persicargas) persicus (Oken, 1818) (Ixodida: Argasidae) is today considered native in Turanian-Central Asia as a parasite of arboreal nesting birds, and has successfully adapted to coexistence with domestic fowl. Probably via human transport, it has spread throughout the continents, where it survives practically exclusively in association with domestic fowl (chickens, turkeys, Helmeted Guinea fowls, and others) and infrequently pigeons (Hoogstraal et al., 1979, 1981; Hoogstraal, 1985; Keirans \& Durden, 2001). In some countries this tick is the most important poultry ectoparasite (Arends, 2003; Shah et al., 2004; Nicholson

\footnotetext{
* Istituto per lo Studio degli Ecosistemi, CNR, Traversa la Crucca 3, Regione Baldinca, 07100 Li Punti SS, Italia.

** Dipartimento di Protezione delle Piante, Università di Sassari, Italia. *** Dipartimento di Scienze Applicate ai Biosistemi, Sez. di Parassitologia, Università di Cagliari, Italia.

***** Paceco, Trapani, Italia.

**:*** Capaci, Palermo, Italia.

Correspondence: Roberto A. Pantaleoni

Tel.: +390792841403 - Fax: +390792841499

E-mail: r.pantaleoni @ ise.cnr.it
}

et al., 2009). It is rare in modern poultry production, but it finds a habitat very compatible with its biology in breeding houses (Axtell, 1999).

Beginning more or less fifty years ago, through the use of the SEM (scanning electron microscope) and above all a virological-biosystematic approach, the interpretation of this taxon has changed dramatically with the discovery of closely related species (describing them as new or resurrecting incorrect synonymies) put together in the subgenus Persicargas Kaiser, Hoogstraal \& Kohls, 1964 (Hoogstraal et al., 1979; Hoogstraal, 1985). So numerous old published records of $A$. persicus became doubtful and the distribution of this species needed to be confirmed often (e.g. Easton, 2006). Nevertheless its presence in America (Kohls et al., 1970; Keirans \& Durden, 2001), Africa (Eastwood, 1972; Sylla et al., 2004), India (Gosh et al., 2007), Australia (Petney et al., 2004) is sure nowadays.

In western parts of its palearctic areal this tick is known in the Middle East, Egypt, Libya and Maghreb on the Southern Mediterranean side and Anatolia, the Balkans (reaching Slovakia in the North and Trieste, Italy, in the West), Corsica and Spain in the North (Rageau, 1972; Doss et al., 1978; Nosek et al., 1980; Manilla, 1986, 1998; Travassos Santos Dias, 1994; Osacar-Jeminex et al., 1998; 
Anonymous, 1999, 2000, 2001). Apparently there are not any sure records for Italy, excluding the only one from Trieste very near to the oriental boundary with the Balkans (Starkoff, 1958b; Manilla, 1998; Iori et al., 2005). Recently, in two sites of the province of Trapani (Western Sicily), some overwintering specimens of an argasid tick belonging to Argas (Persicargas) were observed and collected. Morphological and genetic analyses were utilized in order to reach a definitive identification. This record, the first regarding Sicily and South Italy, will be discussed together with the previous doubtful citations for Italy.

\section{MATERIALS AND METHODS}

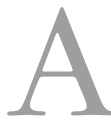

Leica MZ16 stereo microscope and a Leitz Diaplan FSA/20 microscope were used both for morphological observations and for photographs taken with a Leica DFC320 digital camera and LAS (Leica Application Suite) applied software Version 2.5.0 R1.

The DNA extraction was obtained from a single leg of two specimens (one for each site described in the "Results") using the salting-out protocol (Miller et al., 1988). 16S rDNA PCR amplifications and sequencing were performed using primers and conditions as previously described in Petney et al. (2004). The 16S gene portions were aligned in Clustal X ver. 1.64b (Thompson et al., 1997) with representative argasid tick $16 \mathrm{~S}$ sequences, searched on GenBank (www.ncbi.nlm.nih. gov). We carried out a phylogenetic reconstruction by Maximum Parsimony (MP), (Kluge \& Farris, 1969) and Neighbour-Joining (NJ) (Saitou \& Nei, 1987) analyses using PAUP 4.0, b. 10 (Swofford, 2001) and by the Bayesian method using MrBayes 3.1 (Ronquist \& Huelsenbeck, 2003). Neighbour-Joining trees were constructed with distances computed using the best-fit model obtained with MODELTEST 3.04 (Posada \& Crandall, 1998). The GTR model was the best one selected (Tavarè, 1986), corrected for rate heterogeneity among sites with a Gamma distribution (Yang, 1993). MP was carried out using the heuristic search algorithm, with 100 random-taxon-replicates for all analyses. The analysis was performed with ACCTRAN optimization and tree bisection TBR branch swapping, considering all characters as unordered and equally weighted, and gaps treated as fifth state. A strict consensus tree was calculated when there was more than one tree. Non-parametric bootstrapping with heuristic searches of 2000 replicates for MP and NJ was used to assess confidences of branches in MP and NJ. The Bayesian analysis was performed with clade support assessed by posterior probability. Four Markov chains, one heated and three cold, were allowed to run for 2 million generations using random starting trees. Trees were sampled every
100 generations, yielding 8,000 samples of the Markov chain after a "burn-in" of 2,000 generations.

A sequence from a species (Ornithodorus gurneyi, Warburton, 1926, GenBank Acc. No AY436767) belonging to subfamily Ornithodorinae, the sister-group of subfamily Argasinae, and already utilized in previous studies (Petney et al., 2004) was chosen as an outgroup. Besides, some argasid tick sequences, found in GenBank, are used as a comparison and included in the analyses.

\section{RESULTS}

\section{FINDINGS}

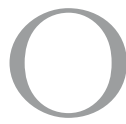
n 2 February 2008 in site A (see below), some specimens of an argasid tick were observed and photographed in nature during winter entomological samplings under the bark of Eucalyptus camaldulensis Dehnhardt, 1832. In the following winter, on 8 December 2008, the same observation recurred in site B. Consequently ad boc researches were repeated on 21 December 2008 (site B) and 17 January 2009 (site A) collecting the specimens listed below.

Site A was in the Natural Reserve "Foce del Fiume Belice", Castelvetrano, Trapani (Sicily), $37^{\circ} 34$ ' 44" N $12^{\circ} 53^{\prime} 15^{\prime} \mathrm{E}$; site B in Misiliscemi Guarrato, Trapani (Sicily), 37० 55'01" N - 12०33' 57" E.

Both sites contain small groups of isolated River Red Gum trees which were isolated (site A) (Fig. 1C, 1E) or near a deserted house (site B) (Fig. 1B, 1D), in neither case were there poultry nearby. Old nests of mediumsized unknown birds were present. Probably they belong to the Common Magpie, Pica pica Linnaeus, 1758 , less probably they should be looked for among arboreal Columbidae, other Corvidae or small Falconidae.

\section{MATERIAL EXAMINED}

Site A: 1 male, 1 female conserved by ISE-CNR Sassari (1 female utilized for genetic analysis), 1 female by section of Parasitology DipSAB Cagliari; site B: 2 males, 1 female, 2 nymphs by ISE-CNR Sassari (1 nymph utilized for genetic analysis), 3 males, 2 females by section of Parasitology DipSAB Cagliari. All specimens have been stored in $70 \%$ or $95 \%$ ethanol.

\section{MORPHOLOGY}

All specimens, without ventral paired organs, have oval idiosoma, wider behind (Fig. 1F). Postpalpal setae are present. The anterior subdorsal seta of tarsal segment IV is single. The peripheral cells of the dorsum have a single large setiferous pit occupying most of the surface area; the cells are large, mostly rectangular or sub-rectangular 


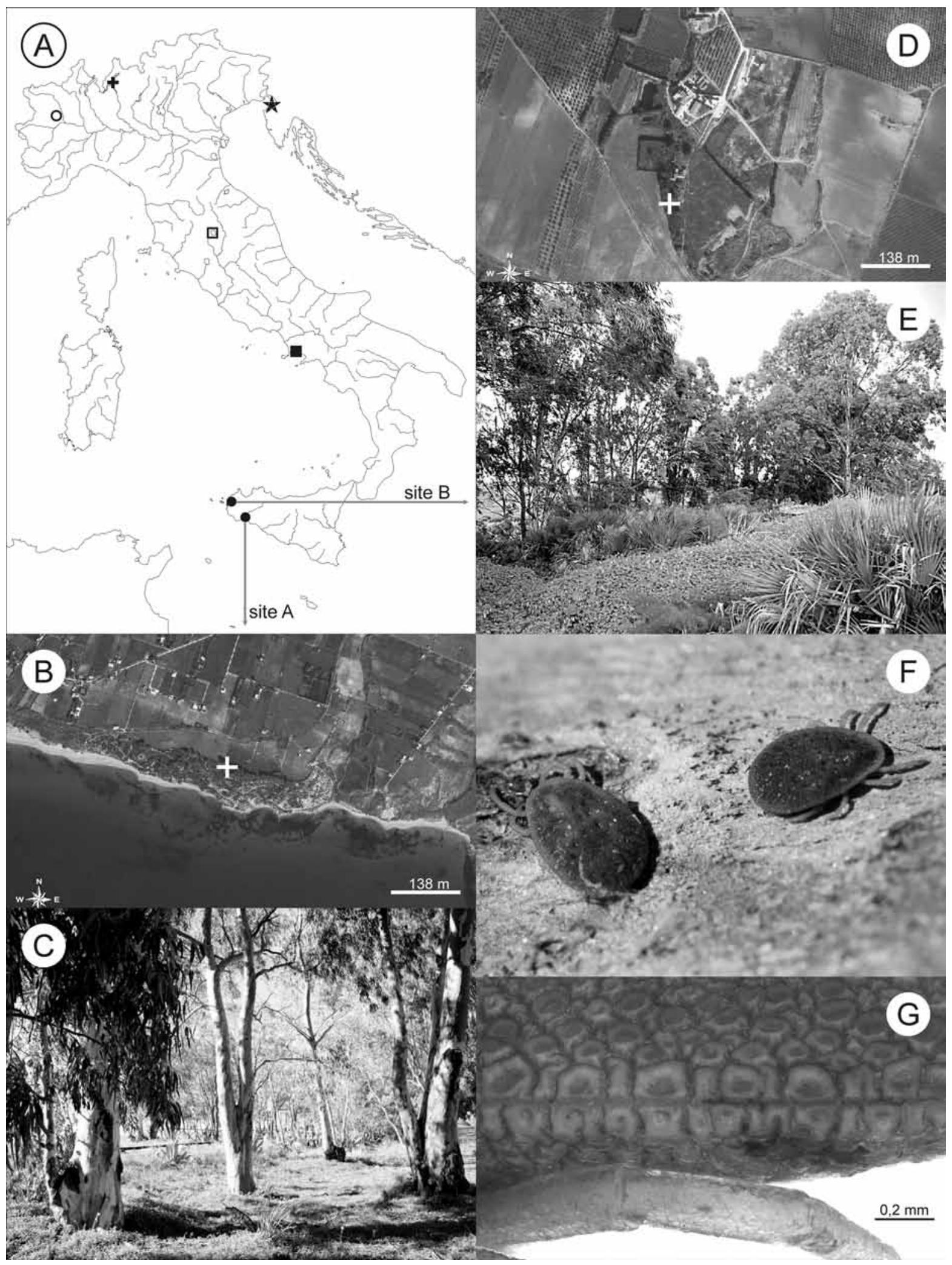

Fig. 1. - A) Argas persicus: map of records in Italy; star = Starkoff (1958a, b, 1959) and Manilla (1990 [1991]); cross = Walter \& Massa (1987); open circle = Durio et al. (1982) and Manilla (1982); open square = Tarello (2001) and Tarello \& Riccieri (2003); solid square = Latreille (1824); solid circles = new sites. B) Natural Reserve "Foce del Fiume Belice", Castelvetrano, Trapani (Sicily), aerial photography (by Google Earth); white cross = site A. C) The same, landscape photography of site A (by Marcello Romano). D) Locality Misiliscemi Guarrato, Trapani (Sicily), aerial photography (by Google Earth); white cross = site B. E) The same, landscape photography of site B (by Luigi Barraco). F) Two specimens of Argas persicus on River Red Gum, after the removal of the bark, in site A (by Marcello Romano). G) Argas persicus: peripheral cells of dorsum. 
(Fig. 1G). These and other morphological characteristics (integument, capitulum, genital area, legs, etc.) fit very well with the descriptions of Argas (Persicargas) persicus (Oken, 1818) provided by Kaiser et al. (1964), Filippova (1966), Khols et al. (1970), Manilla (1998).

\section{GENETIC ANALYSIS}

The two Sicilian sequences of the $16 \mathrm{~S}$ gene fragment (448bp) were identical and have been registered by GenBank under No GU451248. The nucleotide divergences among this sample and the other Argas sequences published in GenBank ranged from 0,5\% (with $A$. persicus from Australia) to $16 \%$ (A. vulgaris AF401404 and A. polonicus AF401403). The phylogenetic reconstruction showed that the closest relative to the argasids from
Trapani (Sicily) were other $A$. persicus samples, as suggested by morphological investigations. All sequences belonging to $A$. persicus indeed constitute a cluster separated from the other Argas species in all phylogenetic analyses, supported by high bootstrap and posterior probability values (Fig. 2).

\section{DISCUSSION}

he identification, as Argas (Persicargas) persicus, of the argasid ticks from Sicily is certain. Both morphological and genetic analysis confirm it. The latter was indispensable due to the lack of keys to identify the species of the subgenus Persicargas (or the

Ornithodorus gurneyi AY436767

Argas reflexus AF001401

Argas robertsii AY436768

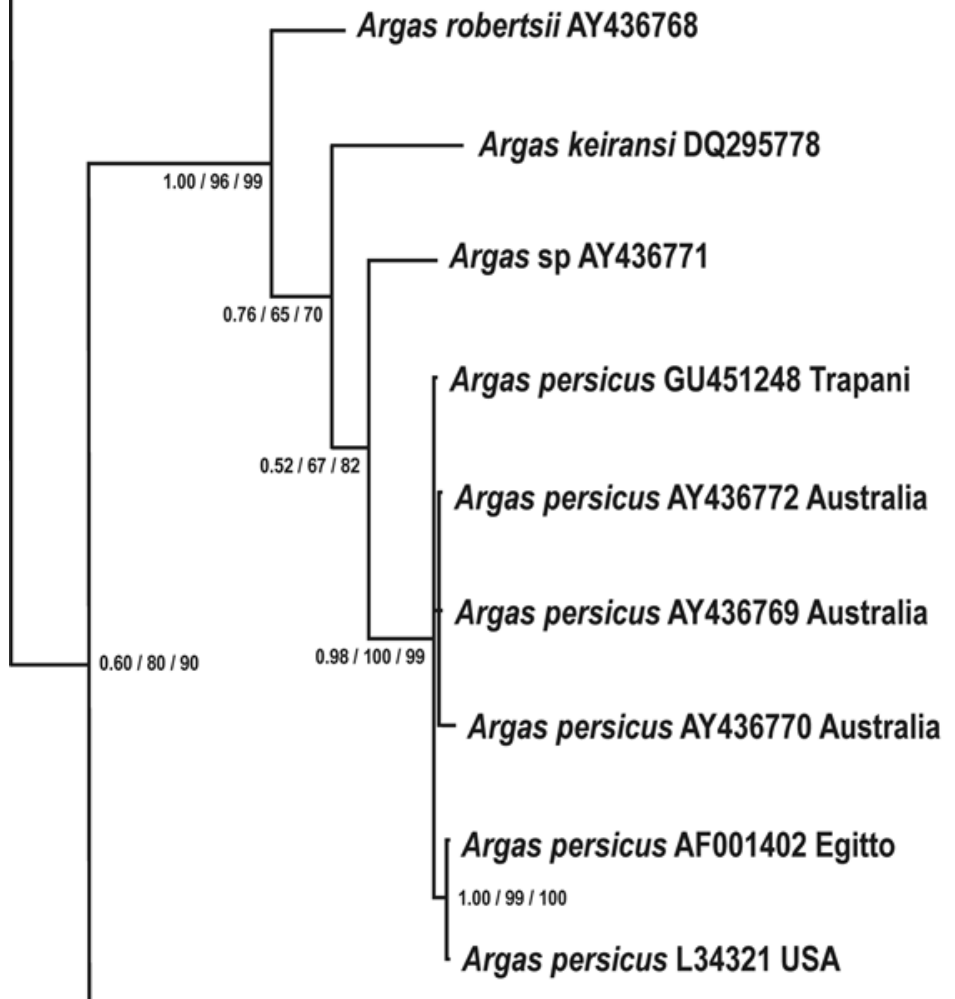

Argas monolakensis L34305

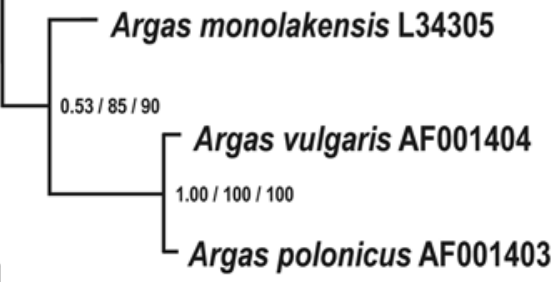

Fig. 2. - Consensus of proposed phylogenetic relationships obtained with the $16 \mathrm{~S}$ data. The consensus diagrams summarize the results of the three reconstruction methods, with their support values for single nodes, Bayesian posterior probability, MP and NJ bootstrap values at the nodes. Argasid tick sequences as found in GenBank are included. 
corresponding group of species following Klompen \& Oliver, 1993).

All Italian records of this species, with two exceptions, were ancient and not well-documented (Fig. 1A). Starkoff (1958a, 1958b, 1959) found A. (P.) persicus in the collection of the Natural History Museum of Trieste. The specimens, mixed with Argas (Argas) reflexus (Fabricius, 1794), were sampled in a loft (infested by pigeons) in Trieste, a city in the furthest East of Italy, near the Balkans. This record was paired by Manilla (1990 [1991]) who reported the finding in poultry-pen near Trieste. These are considered the only two sure records for Italy by both Manilla (1998) and Iori et al. (2005). Starkoff (1958a, 1958b, 1959), like Manilla (1982) at first, was convinced that the species was following the expansion of the Collared Dove, Streptopelia decaocto (Frivaldszky, 1838), from the Balkans to the West. So he immediately rejected an ancient citation of Latreille (1824) for Naples. A second very confused record was that of Manilla (1982) who reports a personal communication regarding a finding on an owl (Strigiformes) in Piedmont: but this record corresponds exactly to that of Durio et al. (1982), which appeared in the same issue of the same journal, about a female of $A$. (A.) reflexus (Fabricius, 1794). Afterwards Walter \& Massa (1987) reported a sampling of 107 engorged larvae on the Great Tit, Parus major Linnaeus, 1758, near Lake Como in Lombardy. Finally, in the Checklist of the Italian Fauna, Bernini et al. (1995) cited $A$. (P.) persicus both in North and Peninsular Italy, but in a successive update (Castagnoli \& Nannelli, 2003) the report for Central Italy was rejected. The reason for this is unknown. Lastly, the presence of $A$. (P.) persicus around Lake Trasimeno, via the finding of Aegyptianellainfection on wild birds, was hypothesized by Tarello (2001) and Tarello \& Riccieri (2003).

In the Trapani province the species was found in two semi-natural sites where, having been found repeatedly, its presence does not appear accidental. The Sicilian habitat is very similar to the wild ones described by Filippova (1966) regarding Central Asia. The findings agree very well with the overwintering behaviour of the species when it develops on wild birds (Filippova, 1966). Poultry is absent in the vicinities of the infested trees and, even if possible, a passage from domestic to wild birds appears very improbable. So the presence of $A$. (P.) persicus in Sicily seems to be natural, excluding a human-induced spread.

Surely these findings have been favoured by the peculiar, easy to inspect, smooth bark of the River Red Gum, which is shed in long ribbons. In other situations the observation of this species could be very difficult and actually, except in Central Asia, the species was rarely collected in its natural habitat (Filippova, 1966).

These records revalue not only all the old citations for Italy but also the hypothesis that the Mediterranean distribution of this argasid is of a natural origin (rejected by Hoogstraal et al., 1979). A Central-Asian-Mediterranean distributional pattern is, as a matter of fact, recognized and common (Vigna Taglianti et al., 1992). Species with this distributional pattern can be very abundant in Central Asia but scarce, rare or scattered in the Mediterranean area. The natural expansion of $A$. (P.) persicus in the Saharo-Sindian and Indo-Malayan regions would be natural via migrating birds as demonstrated in other tick species by Hoogstraal et al. (1961, 1963).

\section{CONCLUSIONS}

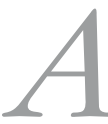
rgas (Persicargas) persicus is commonly considered a highly specialized wide-spread ectoparasite of chickens. The risk of its vector activity is high above all in traditional poultry houses, but not in modern ones. In the NW-Mediterranean countries, Italy, France, Spain and Portugal, the risk seems generally low (see for example the analysis of [Simpson], 2006) both due to the good sanitary conditions of poultry breeding and for the record scarcity of this species in wild habitats.

Nevertheless it is very difficult to find $A$. (P.) persicus in natural habitats, mainly as overwintering adults, and its populations can be easily underestimated. Its distribution in NW-Mediterranean could be not only natural but also much vaster than believed. Even if presently this argasid is really rare, the alert level should be high. The number of suitable habitats could increase as a result of global climatic change. Consequently the contact between wild and domestic birds could also increase, causing pathogen transmission and major damage to farms.

\section{ACKNOWLEDGEMENTS}

The authors wish to thank Albertina Bernardi Iori, of the Department of Public Health Sciences "G. Sanarelli" - University "La Sapienza" of Rome, for providing references. Gario Zappi for his indispensable translation of some parts of the Filippova book. Bruno Massa, of the S.En.Fi.Mi.Zo. Department - University of Palermo, for providing us with information about the probable nesting bird species. Two anonymous referees for their valuable comments on the manuscript.

\section{REFERENCES}

Anonymous. Regional disease vector ecology profile: The Middle East. Defense Pest Management Information Analysis Center, Armed Forces Pest Management Board, Forest 
Glen Section, Walter Reed Army Medical Center, Washington, 1999, 212 pp.

AnONYmous. Regional disease vector ecology profile: North Africa. Defense Pest Management Information Analysis Center, Armed Forces Pest Management Board, Forest Glen Section, Walter Reed Army Medical Center, Washington, 2000, 173 pp.

ANONYmous. Regional disease vector ecology profile: Central Europe. Defense Pest Management Information Analysis Center, Armed Forces Pest Management Board, Forest Glen Section, Walter Reed Army Medical Center, Washington, 2001, 216 pp.

ARENDS J.J. External parasites and poultry pests, in: Diseases of poultry (11 ${ }^{\text {th }}$ Ed.). Saif Y.M. (ed.), Iowa State Press, 2003, 905-930

AXTell R.C. Poultry integrated pest management: Status and future. Integrated Pest Management Reviews, 1999, 4, 53-73.

Bernini F., Castagnoli M. \& Nannelli R. 24 Arachnida Acari, in: Checklist delle specie della fauna italiana. Minelli A., Ruffo S. \& La Posta S. (eds), Ed. Calderini, Bologna, 1995, $131 \mathrm{pp}$.

Castagnoli L. \& Nannelli R. Aggiornamenti alla Checklist delle specie della fauna italiana. Arachnida Acari (Fascicolo 24). Bollettino della Società entomologica italiana, 2003, 135 (3), 193-207.

Doss M.A., Farr M.A., Roach K.F. \& Anastos G. Ticks and tickborne diseases. IV. Geographical distribution of ticks. Index-catalogue of medical and veterinary zoology. Special publication No. 3. United States Department of Agriculture, Washington, DC, 1978, 648 pp.

Durio P., Durante G. \& Sobrero L. Contributo alla conoscenza della fauna ixodologica italiana. Indagini sulla distribuzione delle zecche del Piemonte e della Liguria. Rivista di Parassitologia, 1982, 43 (3), 345-353.

EASTON E.R. Comments on the distribution of Argas persicus and A. walkerae. ICTTD Newsletter, 2006, 29, 4-5.

EAsTwood E.B. First Record of Argas persicus from Southern Africa. The Journal of Parasitology, 1972, 58 (2), 251.

[Filippova N.A. Fauna URSS, Aracnida, Vol IV, Is. 3, Argasid Ticks (Argasidae). Academy Sciences URSS, Moscow, 1966, New Series 96, 257 pp.] Филиппова Н. А. Фауна СССР, Паукообразные, Том IV, Вып. 3, Аргасовые Клещи (Argasidae). Академия Наук СССР Зоологический Институт, Москва, 1966, Новая Серия, 96, 257 рр.

Hoogstraal H., Clifford C.M., KeIrans J.E. \& Wassef H.Y. Recent developments in biomedical knowledge of Argas ticks (Ixodoidea: Argasidae), in: Recent advances in acarology. Rodriguez J.G. (ed.), Academic Press, 1979, 2, 269-278.

Hoogstraal H., Kaiser M.N., Traylor M.A., Gaber S. \& Guindy E. Ticks (Ixodoidea) on birds migrating from Africa to Europe and Asia. Bulletin de l'Organisation mondiale de la Santé / Bulletin of the World Health Organization, 1961, 24, 97-212.

Hoogstraal H., Kaiser M.N., Traylor M.A., Guindy E. \& GABER S. Ticks (Ixodoidea) on birds migrating from Europe and Asia to Africa, 1959-61. Bulletin de l'Organisation mondiale de la Santé/Bulletin of the World Health Organization, 1963, 28, 235-262.
Hoogstraal H., Wassef H.Y. \& BütTiker W. Ticks (Acarina) of Saudi Arabia Fam. Argasidae, Ixodidae. Fauna of Saudi Arabia, 1981, 3, 25-110.

HoogstraAl H. Argasid and Nuttalliellid ticks as parasites and vectors. Advances in Parasitology, 1985, 24, 135-238.

Iori A., Di Giulio A. \& De Felice S. Zecche d'Italia, in: Zecche. Crignoli G. (ed.), Rolando Editore, Napoli, 2005, 1-199.

Kaiser M.N., Hoogstraal H. \& Kohls G.M. The subgenus Persicargas, new subgenus (Ixodoidea, Argasidae, Argas). 1. A. (P.) arboreus new species, an Egyptian Persicus-like parasite of wild birds, with a redefinition of the subgenus Argas. Annals of the Entomological Society of America, 1964, $57(1), 60-69$.

Keirans J.E. \& Durden L.A. Invasion: Exotic ticks (Acari: Argasidae, Ixodidae) imported into the United States. A review and new records. Journal of Medical Entomology, 2001, 38 (6), 850-861.

KLOMPEN J.S. H. \& Oliver J.H. Systematic relationships in the soft ticks (Acari: Ixodida: Argasidae). Systematic Entomology, 1993, 18, 313-331.

KlugE A.G. \& FARris J.S. Quantitative phyletics and the evolution of anurans. Systematics Zoology, 1969, 18, 1-32.

Kohls G.M., Hoogstraal H., Clifford C.M. \& Kaiser M.N. The subgenus Persicargas (Ixodoidea, Argasidae, Argas). 9. Redescription and New World records of $\operatorname{Argas}(P$.) persicus (Oken), and resurrection, redescription, and records of $A$. (P.) radiatus Railliet, $A$. (P.) sanchezi Dugès, and $A$. (P.) miniatus Koch, New World ticks misidentified as $A$. (P.) persicus. Annals of the Entomological Society of America, 1970, 63 (2), 590-606.

LatreIlle P.A. Addition à "Du Mallah de Miana, Insecte de Perse, dit punaise venimeuse". Extrait d'une Notice de Gotthelf Fischer de Waldheim, naturaliste de Moscou ; par M. J.-J. Virey. Journal de Pharmacie et des Sciences Accessoires, 1824, 10, 245.

Manilla G. Zecche (Ixodoidea) ed Uccelli in Italia. Nota II: loro ruolo patogeno. Rivista di Parassitologia, 1982, 43 (3), 367-380.

Manilla G. Distribuzione delle zecche presenti in Italia (Acari, Ixodoidea). Fragmenta Entomologica, 1986, 19 (1), 57-81.

Manilla G. Nuove osservazioni faunistiche e biologiche sulle zecche d'Italia (Acari: Ixodoidea) (Nota V). Atti della Società Italiana di Scienze Naturali e del Museo Civico di Storia Naturale di Milano, 1990 [1991], 131 (28), 433-441.

Manilla G. Fauna d'Italia, XXXVI, Acari Ixodida. Edizioni Calderini, Bologna, 1998, 280 pp.

Miller S.A., Dykes D.D. \& Polesky H.F. A simple salting-out procedure for extracting DNA from human nucleated cells. Nucleic Acids Research, 1988, 16, 12-15.

Nicholson W.L. Sonenshine D.E., Lane R.S. \& Uilenberg G. Ticks (Ixodida), in: Medical and veterinary entomology. $2^{\text {nd }}$ Edition. Mullen G.R \& Durden L.A. (eds), Academic Press, 2009, 483-532.

Nosek J. Hoogstraal H., Labuda M. \& Cyprich D. Bionomics and health importance of fowl tick Argas (Persicargas) persicus (Oken, 1818) (Ixodoidea: Argasidae). Zeitschrift für Parasitenkunde 1980, 63 (3), 209-212. 
Osacar-Jeminex J.J., Estrada-Pina A. \& Lucientes-Curdi J. Ticks (Acarina: Ixodidae) of wild birds in the Ebro Middle basin (North-east Spain). Acarologia, 1998, 39 (1), 23-31.

Petney T.N., Andrews R.H., McDiarmid L.A. \& Dixon B.R. Argas persicus sensu stricto does occur in Australia. Parasitology Research, 2004, 93 (4), 296-299.

Posada D. Using Modeltest and PAUP* to select a model of nucleotide substitution, in: Current protocols in bioinformatics. Baxevanis A.D., Davison D.B., Page R.D. M., Petsko G.A., Stein L.D. \& Stormo G.D. (eds), John Wiley \& Sons, 2003, 6.5.1-6.5.14.

Posada D. \& CRANDAll K.A. Modeltest: testing the model of DNA substitution. Bioinformatics, 1998, 14 (9), 817-818.

RAGEAU J. Repartition geographique et role pathogene des tiques (Acariens : Argasidae et Ixodidae) en France. Wladomosci Parazytologiczne, 1972, 18 (4-5-6), 707-719.

RonQuist F. \& HuELSENBECK J.P. MRBAYES-3: Bayesian phylogenetic inference under mixed models. Bioinformatics, 2003, 19, 1572-1574.

SAITOU N. \& NeI M. The Neighbor-joining method: a new method for reconstructing phylogenetic trees. Molecular Biology and Evolution, 1987, 4, 406-425.

Shah A.H., Khan M.N., IQBal Z. \& SAJID M.S. Tick infestation in poultry. International Journal of Agriculture E Biology, 2004, 6 (6), 1162-1165.

SIMPSON B. Import risk analysis: Passerine hatching eggs from the European Union. Biosecurity New Zealand, Ministry of Agriculture and Forestry, Wellington, New Zealand, 2006, $246 \mathrm{pp}$.

STARKOFF O. Sulla presenza in Italia di Argas persicus. Archivio italiano di scienze mediche tropicali e di parassitologia, 1958a, 38, 3-5.

STARKOFF O. Ixodoidea d'Italia studio monografico. Il Pensiero Scientifico, Roma, 1958b, 385 pp (cfr. 69-73).

STARKOFF, O. Su alcune specie di Ixodoidea segnalate per la prima volta in Italia. Parassitologia, 1959, 1 (2), 83-89.

SwOFForD D.L. PAUP-Phylogenetic analysis using parsimony. Champaing (IL): Illinois Natural History Survey, 2001.

Sylla M., Pourrut X., Faye N., BÂ K., Cornet J.P. \& Camicas J.L. Argasidae (Acari Ixodida) parasites of wild and domestic animals in Senegal: 1 review and distribution. Acarologia, 2004, 44 (3-4), 137-150.

TARello W. Aegyptianella-Like organisms and microfilariae in a severely diseased Bittern (Botaurus stellaris stellaris). Revue de Médecine Vétérinaire, 2001, 152 (2), 189-193.

TARello W. \& Riccieri N. Aegyptianella-like inclusion bodies in two birds of prey from central Italy. Revue de Médecine Vétérinaire, 2003, 154 (11), 715-717.

TAVARÉ S. Some probabilistic and statistical problems in the analysis of DNA sequences. Lectures on Mathematics in the Life Sciences, 1986, 1, 57-86.

Thompson J.D., Gibson T.J., Plewniak F., Jeanmougin F. \& Higgins D.G. The ClustalX windows interface: flexible strategies for multiple sequence alignment aided by quality analysis tools. Nucleic Acids Research, 1997, 25, 4876-4882.
Travassos Santos Dias J.A. As carraças (Acarina-Ixodoidea) da Península Ibérica: algumas considerações sobre a sua biogeografia e relacionamento com a ixodofauna afropaleárctica e afrotropical. Estudos, ensaios e documentos 158. Instituto de Investigação Científica Tropical, Lisboa, 1994, $163 \mathrm{pp}$.

Vigna Taglianti A., Audisio P.A., Belfiore C., Biondi M., Bologna M.A., Carpaneto G.M., De Biase A., De Felici S., Piattella E., Racheli T., Zapparoli M. \& Zoia S. Riflessioni di gruppo sui corotipi fondamentali della fauna W-paleartica ed in particolare italiana. Biogeographia, Lavori della Società Italiana di Biogeografia, 1992, 16, 159-179.

WALter G. \& MAssa R. Ein Beitrag zur Ektoparasitenfauna der Zugvögel in Norditaliaen. Zeitschrift für angewandte Entomologie, 1987, 103 (5), 523-527.

YANG Z. Maximum-likelihood estimation of phylogeny from DNA sequences when substitution rates differ over sites. Molecular Biology and Evolution, 1993, 10, 1396-1401.

Reçu le 31 mars 2010

Accepté le 9 juin 2010 